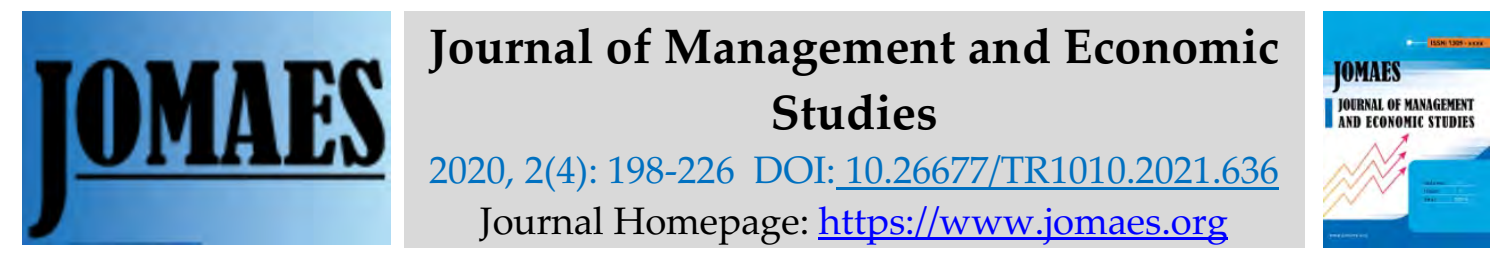

\title{
TQM and Six Sigma: A Literature Review of Similarities, Dissimilarities and Criticisms
}

\author{
Lamine Kaouthar \\ Sousse University, Department of Management, Higher Institute of Management of Sousse, 621, \\ Street Boughouta City Erriadh 4002 Sousse, Tunisia. \\ kaouthar.elamine@gmail.com \\ http://orcid.org/0000-0002-3527-1578
}

\begin{abstract}
This paper discusses the similarity and dissimilarity between TQM and Six Sigma methodologies. Specifically, it contributes by revealing the resemblances and divergences between CSF's of TQM and Six Sigma. The discussion arises firstly based on the considerable criticismsappears in the literature concerning this controversy: Six Sigmais a repackage of TQM or Six Sigmais an extension of TQM?. As of interest to resolve this controversy, a research framework is developed preceded by a theoretical background of the basics, strategies, objectives and CSF's of each methodology. The primary proposition of this work is that the implementation of Six SigmaCSF's are based on the major part on the TQM CSF's. Firstly, this paper reveals that Six Sigmais an extension of TQM and stresses its distinguished characteristics compared to TQM.
\end{abstract}

Keywords: TQM, six sigma, similarities and dissimilarities, critical success factors (CSF's), literature review.

\section{Introduction}

The Six Sigmaquality enhancement approach has obtained recognition in the previous few years as more and more corporations affirm its effectiveness in developing their bottom lines. Companies need to focus on creating Six Sigma projects that are aligned to the business needs (e.g. creating more customers and cash). Customers increasingly require on the quality of the supplied product which leads companies to strive excellence or at least to strive for perfection in order to satisfy more customers. This paper discusses the similarities and dissimilarities between TQM and Six Sigma. We consider that such discussion is essential for these subsequent reasons: to specify the distinguished characteristics of each methodology, to clarify the principal criteria of TQM presented in Six Sigma and to stress the value added of Six Sigma approach.

Firstly, from a TQM perspective, this discussion emphasizes on the importance of TQM as an evolving system of practices, tools, and training methods for managing companies to provide customer satisfaction in a rapidly changing world (Shiba, Graham,\& Walden,1993; Hellsten \& 
Klefsjo,2000). However, the intensification of competiveness and the fluctuation of industrial market were pushing the companies to ameliorate their products quality and services in order to maintain their place in the market. Secondly, Six Sigma is different from other process enhancement methodologies; so it will be precious to examine its impact on performance. Nevertheless, due to its similarity with other process development approaches, such as TQM, it is important to know its particularity (Shafer \& Moeller, 2012).In this respect, the particular question can thus raise: What are the similarities and dissimilarities between TQM and Six Sigma based on CSFs?. Thirdly, the positive impact of Six Sigma approach has been the subject of various perspectives and criticisms and has gained considerable attention for both scholars and practitioners (Hoerl, 1998; Rucker, 2000; Roberts, 2004; Johnson, 2005; Foster, 2007).In spite of the well reputation of Six Sigma approach, there are small theories that stress the effectiveness of Six Sigma projects on organizational performance.

Some consider Six Sigma as an old approach in the new bottles or features. It is just a repackaging of habitual quality management which leads to various criticisms of quality system (Dahlgaard \& Dahlgaardark, 2006). In view of that, there is a necessity to enhance the comprehension of the organizational program and the quality management project in order to have an exact point of view that can reduce vigilance against the implementation of Six Sigma method. Reviewing the historical quality management considering the TQM actions and Six Sigma, the approach of quality management development can be separated into two steps, namely PDCA management cycle associated with TQM activities and the DMAIC technique is linked to Six Sigma project.

Finally, this discussion on the similarities and dissimilarities between TQM and Six Sigma is important because conflicting arguments appear in the literature in regard if this relationship. This paper, therefore, look for resolving this debate from a theoretical perspective, thus leading to the development of suitable research work facilitating the understood of the relationship between TQM and Six Sigma.

The reminder of this paper is structured as follows. Section 2 provides an over view of TQM and Six Sigma foundation, concepts, basic practices.Section3 reveals the similarities and dissimilarities between TQM and Six Sigma based on CSFs. Section 4 stresses the main criticisms raised against TQM and Six Sigma and outlines the principal impediments of Six Sigma and the insufficiencies of TQM.

\section{Literature review on TQM and Six Sigma}

\section{Historical essence of Quality Management}

The competitiveness of Japanese industries in the end of the 1970s had equaled or goes beyond the American industries. Generally, this was owing to the Japanese implementation of companywide quality control (CWQC), (Powell, 1995). In eighteen years, Japanese CWQC had been simulated in the United States, and TQM rapidly became the dominant business strategy implemented by the industries all over the world.

The success of Japanese industries in implementing the TQM offers the opportunity to benefit from the production of excellent products at poorer cost. The popularity of "total quality" term begin in the USA in the 1970s, referred to the variety of Japanese basics resolution for quality, that facilitated Japanese economy restructure after the second world war. The establishment of TQM practices started in Japan in 1950s with huge contribution of American statisticians such as: 
Deming and Juran. TQM confirmed to be a very successful management program and set of techniques and tools. TQM concepts have governed the management prospect for a few decades. In worldwide, a lot of organizations have tried to exploit TQM to attain an improvement of competitiveness and enhancement of financial results.

The field of quality was marked by the emergence of various management systems; one of these is the TQM. The definition of TQM approach can be assimilated to a holistic management philosophy focalized in the preservation and the continuous improvement of all activities inside an organization(Flynn, 1994). "TQM has become a core competency for firms that strive to achieve longterm business success. Consequently, firms have conferred an increasing importance on management practices based on quality, since these aim to eliminate sources of error and inefficiencies, which, in turn, can improve a firm's performance in terms of meeting customer requirements, and increasing organizational performance and employee job satisfaction". (Hackman \& Wageman, 1995).

\section{Total Quality Management Concept}

TQM has embodied several definitions which have existed during the years. Dahlgaard, Kristensen, \& Kanji, (1998) consider TQM as a corporate culture characterized by increased customer satisfaction through continuous improvement, in which all employees in the firm actively participate. Shiba et al. (1993), on the other hand, argue that TQM is an evolving system of practices, tools, and training methods for managing companies to provide customer satisfaction in a rapidly changing world. Hellsten \& Klefsjo (2000) maintain the vision that TQM is an evolving system... as a continuously evolving management system consisting of values, methodologies and tools, the aim of which is to increase external and internal customer satisfaction with a reduced amount of resources.

\section{Essential Basics of TQM Practices}

Many research works have studies and investigated the essentials basics and practices of TQM and have studied their link with innovation, performance (Roffe,1999; Sila \& Ebrahimpour 2002; Yang 2003a;Lakhal,Pasin, \& Limam, 2006; Srinivasu, Sreenivasarao, \& Rikkula, 2010).

Sila \& Ebrahimpour (2002) and Yang (2003a) consider these list of principles elements of TQM: customer meeting and satisfaction; learning and training; top management support, commitment, involvement; teamwork; cooperation, employee participation; quality guarantee; quality information system and application; unremitting improvement; suppleness, benchmarking and tactic arrangement; process management; design of product, service and quality control; worker management and ability, and business quality culture.

Agus \& Hassan (2011) investigated four essential basics of TQM practices that are: supplier relationships, benchmarking, quality measurement, and uninterrupted process development. Additional explanations on the four TQM elements are as follows:

- Supplier relations: producers should work strictly and helpfully with providers over the extended period to remove imperfections entirely.

- Benchmarking: Benchmarking return to investigate the best competitive practices to provide a road for lucid and rational performance objectives and to facilitate the identification of prospect for cost, product reliability and extra factors. As a result, efficiency, performance, and effectiveness can be improved (Kotler, 1994; Tillery \& Rutledge, 1991; Zairi, 1998).

- Quality measurement: Quality measurement is an objective direction with steady performance measurement, frequently with the use of statistical analysis. 
- Continuous process improvement: process improvement developed into a practice that maximizes effectiveness and efficiency while improving process control and strengthening internal mechanisms for answering to altering customer requirements (Mann, 1992; Shetty, 1987).

\section{Historic of six sigma}

The launch of Six Sigmamethod began in Motorola by Smith in the late 1980s in the aim to deal with the company's continued problems of responding to the customer's expectations in a costeffective manner (Srinivasu et al., 2010). Motorola is the pioneer in the implementation of Six Sigmamethodology and the application of Six Sigmabecomes widespread and integrated in other companies such as: General Electric (GE), Toyota, IBM, SONY and Nokia.

We can summarize the evolution of Six Sigmain three generations. The first generation focused on the reduction of process variability and the famous example is of Motorola company. The second generation focalized in developing the concept of the defect elimination in order to upgrade the performance of company by the diversities of tools and methods which are brought out in reduction of costs and improving product design. General electric is the suitable example that can be cited in this case regarding the perfect success realized in this decade. The third generation emphasized to create value for all the partners: employees' commodity, customers' satisfaction, suppliers' relationship, and the society in general. Caterpillar and Bank of America are excellent examples of Generation III of Six Sigmacompanies, for the reason that their implementations are focused on creating value for all stakeholders in the broad (Montgomery \& Woodall, 2008).

\section{Six Sigma Concept}

According to Pande (2002) and Eckes (2001)Six Sigmais considered as a 'breakthrough strategy' and more as a holistic quality philosophy. After in-depth studies, there are different manners to define Six Sigmamethodology used by the practitioners and researchers. Three distinctive concepts facilitate the understanding of Six Sigma term. A measure (e.g. it measures a gap between process and perfection). A target (e.g. aims to achieve a level of 3.4 defects per million opportunities). A philosophy (e.g. it based on reducing costs strategy through the decrease of process variability).

\section{The term Six Sigmais descriptive}

The Greek letter sigma $(\sigma)$ is the standard deviation, it's an important measure of variation, employed to describe the variability of the processes. The variation of a process refers to the degree of concentration of all results around the average. Six Sigma refers to the existence of six gap types between the average of the centre of process and the specification limit or nearest service level. Six Sigma is one of the most known mature approaches in industrial organization improvement. It is created to develop the process quality through some indicators which are based on the customer satisfaction. It delivers a business excellence value to customers through its strategic method.

There are several definitions proposed by many authors to underline the concept of six sigma. Some consider it as a strategy that focuses on reducing the variation in process, cutting costs and ameliorating customer satisfaction (Bendell, 2006). Others define it as a business strategy used to improve business profitability, to improve the effectiveness and efficiency of all operations to meet or exceed customer needs and expectations (Kwak \& Anbari, 2006). Andersson, Eriksson, \& Torstensson, (2006) consider it as an improvement program for reducing variation, which focuses 
on continuous and breakthrough improvements. Lucas (2002) asserts that Six Sigmais essentially a methodology for disciplined quality improvement because this quality improvement is a prime ingredient of TQM. Many firms have found that adding a Six Sigmaprogram to their current business system gives them all, or almost all, of the elements of TQM program. Lucas (2002) has thus concluded that: current business system plus Six Sigmaare equal to total quality management. In current years, the Six Sigmamethod became the focus of academic researches. It is considered as a strategic issue of quality improvement based on the increase of process capability and the development of company performance (Dasgupta, 2003; Linderman,Shroeder, Zaheer, \& Choo, 2003; Raisinghani,Ette, Pierce, Cannon \& Daripaly, 2005; Schroeder, Linderman, Liedtke, \& Choo,2008). In the beginning, Six Sigmawas qualified as methodology of quality measurement. In the last few years it was changed to become a sophisticated discipline focused on the improving of the process by the use of various techniques and statistical tools (Knowles, 2011). After a thorough reading of the literature we can classify the Six Sigmaprocess in two complimented perspectives:statistical and business point of view. From statistical point of view, Six Sigmamethods immerge from statistical tools and statisticians. From the business point of view, Six Sigmacan be treated as business strategy focused in the achievement of a great effectiveness and efficiency to realize a suitable profitability and to respond to the customer's needs or to expect them (Antony \& Banuelas, 2001).

\section{Six Sigma Core Practices}

The review of both research studies and practitioner literature on six sigma(Henderson, 2000; Antony \& Banuelas 2002; Zu,Fredendall, \& Douglas,2008; Choo,Linderman, Schroeder 2007a,b; Kwak \& Anbari,2006; Harry\&Schroeder, 2000; Srinivasu et al., 2010)allowsthe identification ofthree criticalpractices linked to Six Sigmaimplementation. These practices are: Six Sigmastructured improvement procedure (DMAIC and DMADV), Six Sigmarole structure, and Six Sigmafocus on metrics.

\section{Six Sigma Structure Improvement Procedure}

The Six SigmaDMAIC (Define, Measure, Analyze, Improve, and Control) method is applied for improving existing processes and looking for incremental improvement, while the Six SigmaDMADV (Define, Measure,Analyze,Design, and Verify) is used for improving new processes or products (Srinivasu et al. (2010)).

\section{Six Sigma Role Structure}

The work of (Linderman et al.,2003; Antony \& Banuelas, 2002; Sinha\&Van de Ven, 2005; Zu et al.,2008) offers a detailed explanations of the Six Sigmaexperts role and functions from the highest level to lowest level. This classification is as flows: Champions, Master Black belt, Black belt, Green belt and Yellow belt.

\section{Six Sigma Focus on Metrics}

The Six Sigmametrics are helpful tools to measure the process variability and to evaluate the company's performance. They allow the conduction of solutions for each DMAIC or DMADV step which is the distinguished characteristics of Six Sigmamethod compared to other quality management. Based on the work of (Natarajan, Senthil, Devadasan, \& Mohan, 2011), we selected these principal tools of Six Sigmasuch as:FMEA (Failure mode and effects analysis), Control charts,DoE (design of experiments), process mapping, flow chart, SIPOC model, correlation studies, and measure ofcapability.

\section{Comparison between TQM and Six Sigma}


Which distinguish Six Sigmaapproach to other programs TQM is linked to the specificity of Six Sigmawhich is a global approach of management structured with advanced statistical tools, its impact in cultural change, the implication and the training of all employees, it is distinguished by the quantifiable and measured tools, organized structure (Dahlgaard \& Dahlgaard-Park, 2006) and the planning in selecting projects to attain zero defects.

Six Sigma approach emphasizes, at first, the critical criteria to the existing customers (Harry, 1998; Dasgupta, 2003; Linderman et al., 2003; Evans \& Lindsay, 2005). Six Sigmaprovides to the organizations the ability to develop into extra ambidextrous by switching two structures (organic and mechanic). The first structure is used to develop new idea; in this case the company realizes an innovation. The second structure used when the company is interested by the efficiency (Schroeder,Linderman, Liedtke, \& Choo, 2008). It is concerned as a challenge, that the double structures offer the advantage of switching both exploitation and exploration, to profit from both efficiency and innovation (March, 1991).

Choo, Linderman, \& Schroeder (2007a) argue the ability of Six Sigmaof maintaining equilibrium between the effective accomplishment and arranged methodology (e.g. technical tools such as quality control) and context (e.g. top management, organizational culture). The other programs of quality management such as: TQM, Business Process Reengineering are concentrated likely to Six Sigmaapproach in boosting rationality and developing organizational process (Hammer \& Champy, 1993; Powel, 1995; Harry \& Schroeder, 2000). However, the Six Sigmamethod is more oriented to reduce the process variability through sophistical and advanced statistical tools and organizational challenge which provide a cultural change.

Anbari (2002) avows that Six Sigma methodology is more wide-ranging compared to their previous quality methods such as (TQM) and Continuous Quality Improvement (CQI). Six Sigmais more distinctive by the use of advanced statistical tools and it is a structured method that can be implemented in different sectors and not restricted to the manufacturing sector. He treats Six Sigma method as follows:

Six Sigma = TQM (or CQI) + Additional Data Analysis Tools + Stronger Customer Focus + Project Management + Financial Results

\section{Similaritiesbetween TQM and Six Sigma}

In the case of similarities between Six Sigmaand TQM, Schroeder et al. (2008) propose these subsequent points:

- Generally TQM and Six Sigmaaccentuate the importance of attaining customer input and the employment of quality function exploitation in product/service design.

- Generally Six Sigmaand TQM call attention to process ownership and have visibly identified processes.

- Generally programs identify the value of top management guidance and sustain.

- Concerning workers, they are stressed by the two approaches. But, the approaches differ in the staff involved. Especially, Six Sigmais inclined to resort on process enhancement experts, whereas TQM accentuates the involvement of every workers, particularly shop floor workers.

- Generally methodologies identifying the significance of gathering and treating quality data.

Table1. Reveal of the authors' vision about the similarities and dissimilarities between TQM and Six Sigma

TQM Six sigma




\begin{tabular}{|c|c|c|}
\hline Concepts & The quality evolution in Japan & $\begin{array}{l}\text { The quality evolution in Japan and } \\
\text { Motorola }\end{array}$ \\
\hline Theory & Focus on customers & No defects \\
\hline Process view & Improve and uniform processes & Reduce variation and improve processes \\
\hline Approach & Let everybody be committed & Project management \\
\hline Methodologies & PDSA (Plan, do, study, act) & $\begin{array}{l}\text { Define, measure, analyze, improve (or } \\
\text { Design), control (or verify) }\end{array}$ \\
\hline Tools & Analytical and statistical tools & Advanced statistical and analytical tools \\
\hline Primary effects & Increase customer satisfaction & Save money \\
\hline Secondary & $\begin{array}{l}\text { Achieves customer loyalty } \\
\text { and improves }\end{array}$ & Achieves business goals and improves \\
\hline Effects & Performance & Financial performance \\
\hline Criticism & $\begin{array}{l}\text { No tangible improvements, } \\
\text { re-demanding, unclear notion }\end{array}$ & $\begin{array}{l}\text { Does not involve everybody, does not } \\
\text { improve customer satisfaction, does not } \\
\text { have a system view }\end{array}$ \\
\hline
\end{tabular}

Source: Andersson et al. (2006)

- Substantial accent is agreed to meeting the requirements of the customer also in Six Sigma and TQM. Added details concerning the authors' visions about the similarities and dissimilarities between TQM and Six Sigma are given in Table 1.

\section{Similarities between CSFs of TQM and CSFs of Six Sigma}

In order to assess and to sustain the existence of similarities between the CSFs of TQM and six sigma, the identification of some research works that have been raised in this subject is precious. The questions that can be asked in this field are: What is the difference between the CSFs of TQM and Six Sigma? An outline of the main literature review of CSFs of TQM (Table 2) and Six Sigma (Table 3) is under-mentioned in the aim of assessing the similarities and dissimilarities between the research works focused on the CSFs of TQM and Six Sigmain different period. Many details are illustrated in Table 4 which outlines a literature review of rather general CSFs for Six Sigmaand TQM.

Table2. Literature review of TQM CSFs

\begin{tabular}{|c|c|c|c|}
\hline Title of paper & Journal & Authors & Year \\
\hline \multicolumn{4}{|l|}{ CSFs of TQM } \\
\hline $\begin{array}{l}\text { Critical success factors for total quality } \\
\text { management implementation for in small } \\
\text { and medium enterprises }\end{array}$ & Total quality management & $\begin{array}{l}\text { Yusof \& } \\
\text { Aspinwall }\end{array}$ & 2000 \\
\hline $\begin{array}{l}\text { Critical success factors for TQM } \\
\text { implementation and their impact on } \\
\text { performance of SMEs }\end{array}$ & $\begin{array}{l}\text { International Journal of } \\
\text { Productivity and } \\
\text { Performance Management }\end{array}$ & Salaheldin & 2009 \\
\hline $\begin{array}{l}\text { An investigation on the influence of total } \\
\text { quality management on financial } \\
\text { performance the case of Boutan industrial } \\
\text { corporation }\end{array}$ & $\begin{array}{l}\text { International Journal of } \\
\text { Business and Social Science }\end{array}$ & Shahin & 2011 \\
\hline \multicolumn{4}{|l|}{ TQM and company's performance } \\
\hline $\begin{array}{l}\text { An analysis of the relationship between } \\
\text { total quality management implementation } \\
\text { and organizational performance }\end{array}$ & $\begin{array}{l}\text { Journal of Manufacturing } \\
\text { Technology Management }\end{array}$ & $\begin{array}{l}\text { Demirbag } \\
\text { et al. }\end{array}$ & 2006 \\
\hline
\end{tabular}




\begin{tabular}{|c|c|c|c|}
\hline $\begin{array}{llll}\text { Impact of } & \text { TQM } & \text { on } & \text { company's } \\
\text { performance } & & & \end{array}$ & $\begin{array}{l}\text { International journal of } \\
\text { quality \& reliability } \\
\text { management }\end{array}$ & $\begin{array}{l}\text { Kumar et } \\
\text { al. }\end{array}$ & 2009 \\
\hline $\begin{array}{l}\text { Critical success factors of total quality } \\
\text { management in the Indian automotive } \\
\text { industry (NCR) }\end{array}$ & $\begin{array}{l}\text { International Journal of } \\
\text { Economy, Management } \\
\text { and Social Sciences }\end{array}$ & $\begin{array}{l}\text { Kalra \& } \\
\text { Pant }\end{array}$ & 2013 \\
\hline Methodology & & & \\
\hline $\begin{array}{l}\text { A study of measuring the critical factors of } \\
\text { quality management }\end{array}$ & $\begin{array}{l}\text { International Journal of } \\
\text { Quality \& Reliability } \\
\text { Management }\end{array}$ & Badri et al. & 1995 \\
\hline $\begin{array}{l}\text { Causation or covariation: An empirical re- } \\
\text { examination of the link between TQM and } \\
\text { financial performance }\end{array}$ & $\begin{array}{l}\text { Journal of Operations } \\
\text { Management }\end{array}$ & $\begin{array}{l}\text { York } \\
\text { \&Miree }\end{array}$ & 2004 \\
\hline $\begin{array}{l}\text { Pareto analysis of critical success factors of } \\
\text { total quality management A literature } \\
\text { review and analysis }\end{array}$ & The TQM Magazine & $\begin{array}{l}\text { Karuppusa } \\
\text { mi } \\
\text { \&Gandhina } \\
\text { than }\end{array}$ & 2006 \\
\hline $\begin{array}{l}\text { Measuring critical success factors of TQM } \\
\text { implementation successfully }- \text { a } \\
\text { systematic literature review } \\
\text { Rank of TQM }\end{array}$ & $\begin{array}{l}\text { International Journal of } \\
\text { Production Research. }\end{array}$ & $\begin{array}{l}\text { Hietschold } \\
\text { et al. }\end{array}$ & 2014 \\
\hline $\begin{array}{l}\text { Identifying and ranking critical success } \\
\text { factors for implementation of total quality } \\
\text { management in the Indian manufacturing } \\
\text { industry using TOPSIS }\end{array}$ & Asian Journal on Quality & $\begin{array}{l}\text { Khanna \& } \\
\text { Sharma }\end{array}$ & 2011 \\
\hline $\begin{array}{l}\text { Analysis of critical success factors of } \\
\text { world-class manufacturing practices: an } \\
\text { application of interpretative structural } \\
\text { modelling and interpretative ranking } \\
\text { process. } \\
\text { Classification of CSF of TQM }\end{array}$ & $\begin{array}{l}\text { Production Planning \& } \\
\text { Contro }\end{array}$ & $\begin{array}{l}\text { Haleema et } \\
\text { al. }\end{array}$ & 2012 \\
\hline $\begin{array}{l}\text { Soft total quality management, hard total } \\
\text { quality management, and Organizational } \\
\text { performance relationship }\end{array}$ & $\begin{array}{l}\text { The International Journal of } \\
\text { Management Science }\end{array}$ & $\begin{array}{l}\text { Rahman } \\
\& \text { Bullock }\end{array}$ & 2005 \\
\hline $\begin{array}{l}\text { Exploring soft versus hard factors for total } \\
\text { quality management implementation in } \\
\text { SMEs }\end{array}$ & $\begin{array}{l}\text { International Journal of } \\
\text { Productivity and } \\
\text { Performance Management }\end{array}$ & $\begin{array}{l}\text { Lewis \& } \\
\text { Lalla }\end{array}$ & 2006 \\
\hline $\begin{array}{l}\text { The relationship of performance with soft } \\
\text { factors and quality Improvement }\end{array}$ & $\begin{array}{l}\text { Total Quality } \\
\text { Management\& Business } \\
\text { Excellence. }\end{array}$ & $\begin{array}{l}\text { Abdullahan } \\
\text { d Tari }\end{array}$ & 2009 \\
\hline $\begin{array}{l}\text { Meta-Analysis } \\
\text { Essentials of total quality management: } \\
\text { a meta-analysis. }\end{array}$ & $\begin{array}{l}\text { International Journal of } \\
\text { Health Care Quality } \\
\text { Assurance }\end{array}$ & $\begin{array}{l}\text { Mosadeghr } \\
\text { ad }\end{array}$ & 2014 \\
\hline
\end{tabular}


Table 3. Literature review of Six Sigma CSFs

\begin{tabular}{|c|c|c|c|}
\hline Title of paper & Journal & Author & Year \\
\hline \multicolumn{4}{|l|}{ CSFs of Six sigma } \\
\hline $\begin{array}{l}\text { Key ingredients for the effective } \\
\text { implementation of six sigma program }\end{array}$ & Measuring Business Excellence & $\begin{array}{l}\text { Antony \& } \\
\text { Banuelas }\end{array}$ & 2002 \\
\hline $\begin{array}{l}\text { Factors critical to the success of a Six } \\
\text { Sigma quality program in an } \\
\text { Australian hospital }\end{array}$ & $\begin{array}{l}\text { Total Quality Management \& } \\
\text { Business Excellence }\end{array}$ & Hilton et al. & 2008 \\
\hline $\begin{array}{l}\text { Critical success factors for Six Sigma } \\
\text { implementation }\end{array}$ & $\begin{array}{l}\text { Journal of Contemporary } \\
\text { Research in Management }\end{array}$ & $\begin{array}{l}\text { Swami } \\
\text { Prasad }\end{array}$ & 2010 \\
\hline $\begin{array}{l}\text { Critical success factors of Six Sigma } \\
\text { implementations in Italian companies }\end{array}$ & Int. J. Production Economics & Brun & 2011 \\
\hline $\begin{array}{l}\text { Critical success factors of Six Sigma in } \\
\text { original equipment manufacturer } \\
\text { company in Malaysia }\end{array}$ & $\begin{array}{l}\text { International Journal of } \\
\text { Synergy and Research }\end{array}$ & $\begin{array}{l}\text { Leong } \\
\text { Teh }\end{array}$ & 2012 \\
\hline $\begin{array}{l}\text { An assessment of the critical success } \\
\text { factors for Six Sigma implementation } \\
\text { in Indian industries }\end{array}$ & $\begin{array}{l}\text { International Journal of } \\
\text { Productivity and Performance } \\
\text { Management }\end{array}$ & Desai et al. & 2012 \\
\hline $\begin{array}{l}\text { Critical success factors for Six Sigma } \\
\text { implementation by SMEs }\end{array}$ & $\begin{array}{l}\text { International Journal of } \\
\text { Scientific \& Engineering } \\
\text { Research }\end{array}$ & $\begin{array}{l}\text { Raghunath } \\
\text { \& } \\
\text { Jayathirtha }\end{array}$ & 2013 \\
\hline \multicolumn{4}{|l|}{$\begin{array}{l}\text { Six Sigma and company's } \\
\text { performance }\end{array}$} \\
\hline $\begin{array}{l}\text { Six sigma strategy for organizational } \\
\text { excellence }\end{array}$ & $\begin{array}{l}\text { Total Quality Management \& } \\
\text { Business Excellence }\end{array}$ & Thawani & 2004 \\
\hline $\begin{array}{l}\text { Six sigma, organizational learning and } \\
\text { innovation:An integration and } \\
\text { empirical examination }\end{array}$ & $\begin{array}{l}\text { International Journal of Quality } \\
\text { \& Reliability Management }\end{array}$ & $\begin{array}{l}\text { Sony } \\
\text { Naik }\end{array}$ & 2012 \\
\hline $\begin{array}{l}\text { Diagnosing of sustainable competitive } \\
\text { advantage using Six Sigma } \\
\text { methodology }\end{array}$ & $\begin{array}{l}\text { International Journal of } \\
\text { Business and Management }\end{array}$ & $\begin{array}{l}\text { Mahdi \& } \\
\text { Almsafir }\end{array}$ & 2012 \\
\hline $\begin{array}{l}\text { Six Sigma adoption: Operating } \\
\text { performance impacts and contextual } \\
\text { drivers of success }\end{array}$ & $\begin{array}{l}\text { Journal of Operations } \\
\text { Management }\end{array}$ & $\begin{array}{l}\text { Swink } \\
\text { Jacobs }\end{array}$ & 2012 \\
\hline $\begin{array}{l}\text { The effects of Six Sigma on corporate } \\
\text { performance: An empirical } \\
\text { investigation }\end{array}$ & $\begin{array}{l}\text { Journal of Operations } \\
\text { Management }\end{array}$ & $\begin{array}{l}\text { Shafer \& } \\
\text { Moeller }\end{array}$ & 2012 \\
\hline $\begin{array}{l}\text { Linking Six Sigma to business strategy: } \\
\text { an empirical study in Taiwan }\end{array}$ & Measuring Business Excellence & Cheng & 2013 \\
\hline $\begin{array}{l}\text { Investigation of Six Sigma practices } \\
\text { and process innovation }\end{array}$ & $\begin{array}{l}\text { International Journal of } \\
\text { Innovation and Applied } \\
\text { Studies }\end{array}$ & $\begin{array}{l}\text { Khaidir et } \\
\text { al. }\end{array}$ & 2014 \\
\hline $\begin{array}{l}\text { METHODLOGY } \\
\text { Developing an instrument for } \\
\text { measuring Six Sigma implementation }\end{array}$ & $\begin{array}{l}\text { Int. J. Services and Operations } \\
\text { Management }\end{array}$ & Jones et al. & 2011 \\
\hline
\end{tabular}


On some aspects of developing an effective model for

the implementation of Six Sigma

concept in small and medium sized

manufacturing enterprises in India.

\section{Rank of CSF of six sigma}

Fuzzy AHP approach to prioritization of critical success factors for six sigma implementation: evidence from the electronics industry in Thailand Prioritizing critical success factors for Six Sigma implementation using interpretive structural modeling
International
Journal
of Hiregoudar
2011
Management Science and \& Soragao
Engineering Management
$\mathrm{n}$
International Journal of Somsuk
Modeling and Optimization \&Simcharo
en

2011

American Journal of Industrial Alidrisi

\section{Classification of CSF of six sigma}

Six Sigma's critical success factors and toolbox

Six Sigma implementation framework for mid-sized Indian automotive enterprises

\section{Meta-analysis}

Six sigma's success factors: A metaanalytic review

An exploration of six sigma's tools and techniques

\section{Comparative Studies TQM/six sigma}

Six Sigma and total quality management: Different day, same soup?

Similarities and differences between

TQM, Six Sigma and Lean

Mapping the critical links between organizational culture and TQM/ Six

Sigma practices

Total quality management and six sigma: the integration of TQM and sixsigma

Quality management in heavy duty manufacturing industry: TQM vs. Six Sigma
International Journal of Lean Ismyrlis \&

Six Sigma

Moschidis

Int. J. of Business Excellence

Sambhe

2013

\&Dalu

International Conference on Tlapa et al. 2010

Industrial Engineering

International Conference on Tlapa et al. 2010

Industrial Engineering

Int. J. Six Sigma and Klefsjö \& 2006

Competitive Advantage Bergquist

The TQM Magazine

Andersson 2006

et al.

International Journal of Zu et al. 2010

Production Economics

Open Access Chapter $9 \quad$ Yang

Total Quality Management \& Sabet et al. 
Table 4. Literature review of the CSF's of Six Sigmaand TQM

\begin{tabular}{|c|c|}
\hline CSF's & Six Sigma/TQM \\
\hline Business plan and vision & $\begin{array}{l}\text { Coronado and Antony (2002) } \\
\text { Dalton et al. (1996) } \\
\text { Deming (1986) } \\
\text { Henderson and Evans (2000) } \\
\text { Juran (1989) } \\
\text { Tar'' (2005) }\end{array}$ \\
\hline Top-management support (including funding) & $\begin{array}{l}\text { Coronado and Antony (2002) } \\
\text { Dalton et al. (1996) } \\
\text { Deming (1986) } \\
\text { Juran (1989) } \\
\text { Tar'' (2005) }\end{array}$ \\
\hline $\begin{array}{l}\text { Project management (including project champion and } \\
\text { teamwork and composition) }\end{array}$ & $\begin{array}{l}\text { Coronado and Antony (2002) } \\
\text { Tar'' (2005) } \\
\text { Spector (2006) }\end{array}$ \\
\hline Change management & Coronado and Antony (2002) \\
\hline Organizational culture & $\begin{array}{l}\text { Deming (1986) } \\
\text { Dalton et al. (1996) } \\
\text { Juran (1989) } \\
\text { Spector (2006) } \\
\text { Tarı' (2005) } \\
\text { Winter (1994) }\end{array}$ \\
\hline Effective communication & Coronado and Antony (2002) \\
\hline Education and training & Deming (1986) \\
\hline knowledge transfer & Dalton et al. (1996) \\
\hline $\begin{array}{l}\text { knowledge management } \\
\text { (including skills and expertise) }\end{array}$ & $\begin{array}{l}\text { Juran }(1989) \\
\text { Tar'' (2005) } \\
\text { Winter (1994) }\end{array}$ \\
\hline Organizational structure & $\begin{array}{l}\text { Coronado and Antony (2002) } \\
\text { Garvin (1995) } \\
\text { Keen and Knapp (1996) } \\
\text { Tar'' (2005 }\end{array}$ \\
\hline $\begin{array}{l}\text { Monitoring and evaluation of performance: performance } \\
\text { measurements }\end{array}$ & $\begin{array}{l}\text { Deming (1986) } \\
\text { Juran (1989) } \\
\text { Na“slund (1996) }\end{array}$ \\
\hline
\end{tabular}

Source: Näslund (2008)

Initially, we assess the resemblance of the studies developed to investigate the impact of the CSFs of TQM or of Six Sigmaon the company organizational performance, on cultural change, the role of management commitment and support, the importance of training to enhance the employees skills, the impact TQM on financial performance, innovation (Salaheldin, 2009; Shahin, 2011; Kumar, Choisne, Grosbois, \& Kumar, 2009; Demirbag et al., 2006; Kanji \& Yui, 1997). Similarly, Six Sigmastudies focused on the literature review of Six Sigma and its link with the company strategy (Thawani, 2004; Cheng, 2013) link with learning and innovation Sony and Naik (2012); Khaidir et al.,(2014)), and how it brings competitive advantage (Mahdi \& Almsafir, 2012), its impact on the corporate performance (Shafer \& Moeller, 2012). As well, many studies have reviewed and investigated the Six SigmaCSF (Raghunath \& Jayathirtha, 2013; Swink \& Jacobs, 
2012) and its impact on the company performance in different levels such as: cultural, financial, innovation, and training (Antony \& Banuelas, 2002; Brun, 2011; Ismyrlis \&Moschidis, 2013). Others focused on the prioritization of the CSF of six sigma (Somsuk \& Simcharoen, 2011; Alidrisi,2014). Previously, various studies investigated the CSF of TQM using fuzzy method (for example Kutlu \& Kadaifci, 2014; Rezazadeh et al., 2012) focused on the evaluation and prioritization of the critical success factors of TQM implementation based on fuzzy AHP. Similarly, a fuzzy method has been adopted on Six Sigmaby Somsuk \& Simcharoen(2011) whose developed a fuzzy AHP approach to prioritization of critical success factors for Six Sigmaimplementation.

Some studies emphasized on the rank of CSF of TQM like the work of (Khanna, 2011) who stressed the importance of ranking CSFs for implementation of TQM to increase success rate, reduce costs and prevent failure. Others are interested to the adoption of meta-analysis for the essential of total quality management (Mosadeghrad, 2014). Correspondingly, Tlapa,Leal, Amaya, Limón, \& Báez, (2010) developed a meta-analytic review of CSF of six sigma. Various researches developed constructive studies focused on the categorization of TQM practices in to soft and hard and their relationship with organizational performance, such as (Rahman \& Bullock, 2005; Lewis \& Lalla, 2006; Abdullah \& Tari, 2009). In the same way, some studies investigated the soft and hard CSF of six sigma (Kundi, 2005; Ismyrlis \& Moschidis, 2013).

The examination of these studies allows us to conclude that exist a similarities between the CSF of TQM employed and the CSF six sigma. Six Sigmais considered as an extension of TQM in the sense that is based on the CSF of TQM but it is distinguished by its three practices which are: Six Sigma procedure structure, Six Sigma structure improvement procedure and Six Sigmafocuses on metrics. Subsequently, the value added of Six Sigmaconsists on a well structured method, advanced statistical tools and certified experts.

\section{Dissimilarities between TQM and six sigma}

In this part we are interested to reveal the dissimilarities between TQM and Six Sigmain term of strategy, methodology, tools based on SCFs. Many studies of comparison between different quality management approaches have been raised. Andersson et al. (2006) focused on similarities and differences between TQM, Six Sigmaand lean. Na"slund (2008) purpose is to explore if the Six Sigmaand lean are new methods or just a repackage of previous methods. The study is based on a comparative literature review of lean with JIT and Six Sigmawith TQM, and a review of critical success factors (CSF) for change efforts. The value of this research work resides on illuminating the difference between these fourth methods and it analyzed the lessons that can be learnt from organizational change and improvement efforts. Our objective is to stress only the distinctive aspects of Six Sigmaand TQM. Chinvigai,Dafaoui, \& EL Mhamedi, (2007) offers more details about the distinctive characteristic of each approach which are listed below in Table 5 .

Table 5. The differences between TQM and Six Sigma 


\begin{tabular}{|c|c|c|}
\hline & TQM & Six Sigma \\
\hline Origin & Japan & Japan - USA - Motorola \\
\hline Focus on & Increase the customer satisfaction & $\begin{array}{l}\text { - concentrate on reducing } \\
\text { variability } \\
\text { in process or product } \\
\text { - process improvement }\end{array}$ \\
\hline Leadership & Kaizen team and QCC group & Leadership (BB,GB) \\
\hline $\begin{array}{l}\text { Participation in an } \\
\text { organization }\end{array}$ & $\begin{array}{l}\text { the commitment and involvement of } \\
\text { all employees }\end{array}$ & $\begin{array}{l}\text { Employee and innovation } \\
\text { (project teams) }\end{array}$ \\
\hline Process orientation & Process Approach & Business process \\
\hline Methodology & Continuous improvement (PDSA) & $\begin{array}{l}\text { Product and process } \\
\text { improvement } \\
\text { (DMADV and DMAIC) }\end{array}$ \\
\hline $\begin{array}{l}\text { Techniques and } \\
\text { tools }\end{array}$ & Analytical and Quality tools & $\begin{array}{l}\text { Advance statistical and analytical } \\
\text { tools }\end{array}$ \\
\hline Limitation & $\begin{array}{l}\text { - Unclear notion of TQM } \\
\text { - Need to implement in the whole } \\
\text { company together }\end{array}$ & $\begin{array}{l}\text { cannot dramatically improve } \\
\text { process speed or reduce invested } \\
\text { capital }\end{array}$ \\
\hline
\end{tabular}

Source: Chinvigai et al. (2007)

\section{TQM CSFs VS Six SigmaCSFs}

Kalra \&Pant (2013) investigated the critical success factors of total quality management in the Indian automotive industry and offered a literature review of the critical features of TQM based on the work of Black \& Porter (1996) that highlighted eight critical success factors which are : policy and strategic planning, process management and control, suppliers focus and satisfaction, customer focus and satisfaction, human resource focus and satisfaction, information management, quality leadership and organizations specific business results. Additionally, based on literature review of various studies on TQM and six sigma, an outline of key CSFs of TQM(Table 6) and six sigma (Table 7) is shown below.

Table 6.Literature review of the CSFs of TQM implementation

\begin{tabular}{ll}
\hline CSFs for TQM implementation & Literature review \\
\hline Management leadership & Yusof \&Aspinwall (2000) \\
Continuous improvement system & \\
Measurement and feedback & \\
Improvement tools and techniques & \\
Supplier quality assurance & \\
Human resource development & \\
Systems and processes & \\
Resources & \\
Education and training & \\
Work environment & Rahman's (2001) \\
Culture & \\
Leadership & \\
Strategy and planning &
\end{tabular}


Employee empowerment and employee involvement

employee

Training and development

Information and analysis and customer management

Strategic quality management

Dayton (2003)

Quality data and reporting

Demirbag et al. (2006)

Role of top management

Employee Relations

Supplier quality management

Training

Quality policy

Process Management

Top management commitment

Das et al. (2008)

Process quality management

Education and training

Supplier quality management

Employee empowerment and involvement

Benchmarking

Top management commitment

Gaddene \& Sharma (2009)

Education and training;

Supplier quality management

Employee empowerment and involvement

Benchmarking

Top management commitment

Process quality management

Supplier quality management

Customer

Information

Table 7.Literature review of Six Sigma CSFs

\begin{tabular}{ll}
\hline Six Sigma CSFs & Literature review \\
\hline Management commitment and involvement & Antony \& Banuelas (2002) \\
Understanding of Six Sigmamethodology & \\
Tools and techniques & \\
Linking Six Sigmato business strategy & \\
Linking Six Sigmato strategy & \\
Project selection & \\
Review and tracking & \\
\hline
\end{tabular}




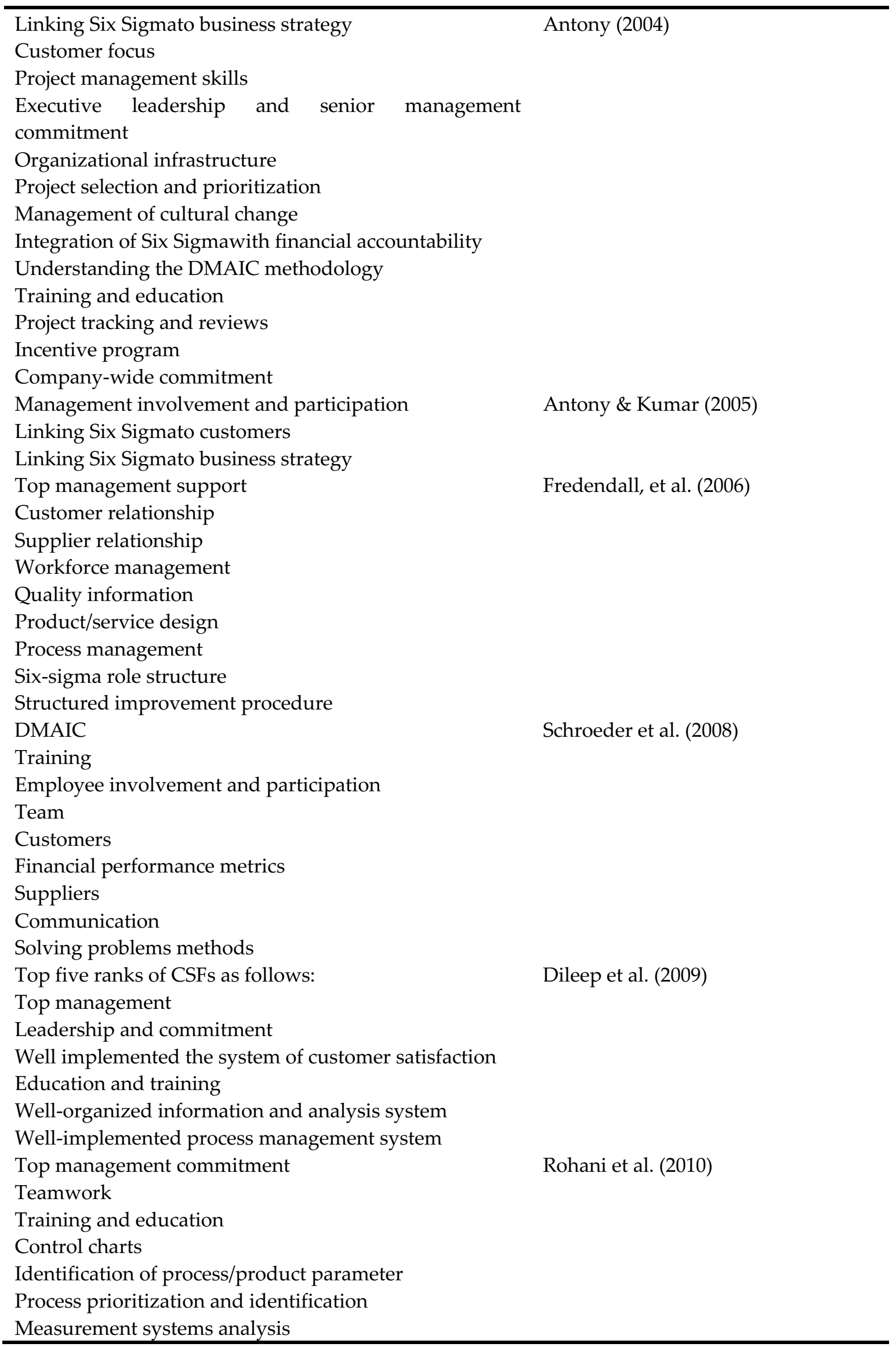


Pilot project

Use of facilitator

Cultural change and deployment

The most inclusive list of success factors of TQM and Six Sigma

Based on the literature review of (Zairi, 2005; Deming, 1986; Juran, 1993; Lloréns-Montes\& Molina, 2006) the most inclusive list of success factors and further researchers in TQM and Six Sigmafield are as follows: top management factor, inclusive of corporate strategy, management leadership, fact-based decision-making, cross-functional project teamwork, reward schemes and explicit and challenging goals; and organizational characteristics factor, inclusive of customer focus, firm internal constraints, organizational culture, continuous training and learning, Six Sigmarole structure and company size.

\section{Criticisms of Six Sigmaand total quality management}

The recent paragraph gives a global idea of the main criticisms developed against Six Sigmaand TQM by stressing the key characteristics of TQM presented in six sigma, the raison of Six Sigmasuccess and the obstacles and insufficiencies of the two approaches(Rahman, 2007 ;Goh, 2010; Jun, Cai, \& Peterson, (2010); Cândido \& Santos, 2011; Grima,Marco-Almagro, Santiago, \& Tort-Martorell,2014).

\section{The main Characteristics of TQM presented in Six Sigma}

According to the point of view of Antony (2009), it exist some of characters of TQM that are imitated in Six Sigmaprogram, "A customer-centric approach; process view of work; a continuous improvement mindset; improving all aspects and functions of the organization; data-based decision making ; and the use of statistical tools on a broad basis". Kedar,Lakhe, Deshpande, Washimkar, \& Wakhare, (2008) consider that Six Sigmaprovides obvious change of structure and is greatly extra orientated on quick and concrete results compared to TQM and Lean. Näslund (2008) highlights that Six Sigmais an advance improvement of TQM. He discovers similarities in the problem solving process (Deming wheel and DMAIC cycle), the value of top management engagement, the crucial worker implication, and in statistical methods.

The dual aspect of Six Sigmaincludes both the "deployment" and "methods and tools" which distinguishes the Six Sigmaapproach from other management projects such as TQM. However the majority of techniques and tools of Six Sigmawere previously employed in TQM program which leads to conclude that are not in fact newness in this case. The addition of Six Sigmaconsists in the well organized structure which focuses on strong difficulties solving techniques and tools based in the DMAIC support (Antony, 2009).

Six Sigma is considered as an Extension of the Total Quality Management

Six Sigmais a helpful management philosophy and problem-solving method, and it is considered as an extension of TQM which is founded on the principles and knowledge of the PDCA management cycle. Lucas (2002) discovers that Six Sigmautilizes a modified PDCA management cycle. In effect, DMAIC is at heart of the Six Sigmastrategy, and intimately look like Deming's PDCA cycle for permanent improvement (Voehl, 2004). Cheng (2008) focused on the relationship between TQM and Six Sigma based on an empirical study of company in Taiwan implementing Six Sigma via TQM improvement. In order to attain the study goal, a conceptual framework has 
been conducted with six improvement factors "system", "product", "control", "training", "technical", and "assessment". The principal finding of this study is that TQM is a prime component and fundamental basis of Six Sigma.

The workhighlights the principals' points of Six Sigmaintegration using TQM activities. In fact, the use of TQM context factors to execute Six Sigmaprograms stressed as follows:

(1) System. The PDCA management cycle is a basic activity for Six Sigmaand DMAIC method is a higher improvement activity. The PDCA management cycle embraces usually improvement activities such as QA and the ISO system. These activities correspond to the vital mechanisms of TQM that cannot be neglected and must be protected when establishing the integration of six sigma.

(2) Product. TQM highlights the accurate actions to decrease defect rates, while Six Sigmais founded on Cpk to diminish the special-cause variation.

(3) Control. The single distinction between TQM and Six Sigmais that TQM is categorized as "inter-organization of quality improvement team" and Six Sigmais as "intra-organization of cross function team". (Cheng, 2008).

(4) Training. The contents of TQM and Six Sigmatraining include basic and advanced courses. TQM teaches basic quality control skills, and Six Sigmamay also use basic quality control skills to integrate DMAIC methodology.

(5) "Technical. TQM and Six Sigmahave intercommunity quality improvement skills; however if TQM technical skills are not completely solid it is impossible to implement the 6- $\sigma^{\prime \prime}$.(Cheng, 2008).

(6) Assessment. TQM and Six Sigmahave approximately the similar quality development indexes for evaluation, such as: yield $\mathrm{Cp}, \mathrm{Cpk}$.

Implementation of Six Sigmavia TQM

Many criticisms have been raised against Six Sigmaand consider it as just a methodology that based on TQM practices and don't create a new practices in field on management. Our objective is to demonstrate the degree of justice. Green (2006) considers the revival of TQM under new name which is six sigma. The work stressed the importance of six sigma structured method(DMAIC) in improving the company's process as well as approvedthat the features of TQM are found in the correct application of six-sigma. Zu et al. (2010) reviewed both the traditional quality management and Six Sigmaliteratures and identified three new practices that are critical for implementing six sigma's concept and method in an organization which are Six Sigmarole structures, Six Sigmastructured improvement procedure, and Six Sigmafocus on metrics and investigate their positive impact in improving the business performance. This research work illuminate that Six Sigmaisn't only a repackages of TQM traditional practices but it complement it.

Yang (2012) focused on the integration of TQM and six-sigma.An over view of TQM principals' elements and Six Sigmacritical particles and tools is offered. Also, it reveal the possibility of the integration of both TQM and Six Sigmapractices and this based on the evidence of the existence of congruence between the quality principles, techniques, and cultural aspects of TQM and Six Sigmaand sustain that exist only a little dissimilarity between their management principles. "As a result, the integration of TQM and Six Sigmais not as difficult as it might seem. The critical task is to combine the best aspects of TQM's continuous improvement with those of Six Sigma re-engineering". (Yang, 2004). Sabet (2014) challenge the debate concerning Six Sigma VS TQM empiricallyin a heavy duty machinery production industry.The results shows that Six Sigma foundation is based on TQM, as well as the finding stress the complementary between the two approaches and not their substitutability. 


\section{The reasons of Six SigmaSuccess compared to TQM}

Globally, Six Sigmaapproach has gained more success compared to TQM. There are many raisons for this; the major one is the focus on projects which have a positive impact on business financial performance (Montgomery \& Woodall, 2008). Additionally, Prajogo\&Sohal (2001) said "The level of technical training in Six Sigmais generally deeper and more extensive than in the typical TQM programs of the 1980s. Also, because the training is project-oriented, it is much more likely that the techniques will actually be used". Hu,Barth, \& Sears, (2005) asserted that Six Sigmamethodology is preferred to TQM approach for these subsequent reasons: While the TQM approach was run by "Quality techies", Six Sigmaapproach implicates the top managers by commitment and involvement. Itfacilitates the success of organizations through the understandable roadmap for integration and exploitation. To guarantee the success in implementing Six Sigmatools and methods, Six Sigmaoffers an appropriate organizational culture and well organized infrastructure.This character was entirely absent in TQM philosophy (Antony, 2009).

Despite the difference in defining the TQM and Six Sigma, the goal of the different concepts appears similar. The aim concerns the improvements and the reduction of waste while increasing customer satisfaction and financial results (Anderson et al., 2006). We conclude by stressing that the strength of Six Sigmaconsists is the well-ordered structure and the efficiency in integrating projects and tools coupled with training for every members of the organization.

\section{Obstacles and Challenges of Six Sigmamethod}

Six Sigmaprograms challenge the development of the processes and focus on decreasing organizational process variability (Linderman et al., 2003; Schroeder et al., 2008). Six Sigmadoesn't change the integrity and interconnectedness of organizational processes; rather, in improves them.

- Problems with strategy

Six Sigmahas attacked with many criticisms. One of the central criticisms is that is considered as doesn't prove a newness and it is a simple repackages of principles and quality tools (Catherwood, 2002).

- Problems with organizational culture

McClusky (2000) considers that the concepts of quality designated to be fixed in process designing more than the control of quality in manufacturing step. The main idea is to move to integrate quality in the planning step. Organizations that not include a full comprehension of the concrete obstacles of Six Sigmaprojects or a switching in planning management faced with a risk of loss. To success a cultural change it is recommend at the first the great implementation of time and commitment.

- Problems with training (Belt Program)

Kwaka \& Anbari (2006) affirm that "training is a key success factor in implementing Six Sigmaprojects successfully and should be part of an integrated approach". Participants want to be aware of the up to day tools and techniques of Six Sigmathan to exchange the new data analysis.

The impediment of six sigma

The weakness of six sigma implementation have been severally discussed in diverges research works (e.i. Douglas and Erwin (2000); Klefsjo et al. (2001); Magnusson et al. (2003); Antony, 2004; Pepper and Spedding, 2010; Brun (2011); Ericsson and Lilliesköld (2014); Aldowaisana et al. (2015). Magnusson et al. (2003) asserted that the impediment of six sigma resides in the difficulty of the six sigma project to go beyond the customer's requirements and thus increase the customer satisfaction. To avoid this problem a number of firms employ voice of the customer technique when the definition of their step. Klefsjo,Wiklund, \& Edgeman, (2001) avowed that Six 
Sigmaproject not success the generation of conditions in the aim of engaging everybody, which is more appeared in the TQM literature. According to Douglas and Erwin (2000) six sigma is focalized to respond to customer needs more than the product. Chakravorty (2009) stressed the need of a an effective model of six sigma implementation and the lack of this guide is one of the reason of the program fail. Brun (2011) interested to study the critical success factors of six sigma in Italian companies. The aim was to reveal if the Italian companies implementing six sigma recognize the same set of critical success factors singled out in the international literature. The analysis showed a lack of literature about six sigma integration in Italian companies. Aldowaisana et al. (2015) analyzed the six sigma performance for non-normal processes. The result reveal some limits of six sigma: reporting the sigma level as an indication of the quality can be misleading. When systematically assuming normality, wrong six sigma projects can be selected which consequently lead to erroneous solutions. Further, Ericsson and Lilliesköld (2014) examined the DFSS implementation strategy in four organizations to find out which parts of the DFSS concept are being used by companies. The finding underlines the shortage of concrete support in DFSS for the activities of product development.

The reasons of Six Sigmafailures

The fall of Six Sigmaproject can be explained by various reasons. The most remarkable one is the lack of guidelines of effective model implementation of projects (Knowles, 2011).Moosa \&Sajid (2010) are interested in their work to explore and to analyze the critical success and failure factors of implementing Six Sigmain organizations based on lessons learned in practices and case studies, as well as available literature. The Six SigmaAcademy suggests the subsequent lists of failed projects raisons which are: the need of the top management engagement, the use of part-time trainers, incorporation of projects attached to irrelevant criteria, the wrong objective, maybe founded on the number of groups educated and licensed rather than bottom-line results; weak project management, treatment of six sigma"quality" project. This list may be extended. (Glibert, 2002). Eckes (2001) argue that 60 percent of projects are unsuccessful due to the negligence of people question, principally the dynamism of group (motivating and driving forces that propel a team toward its goal or mission). He precise numerous difficulties that classically happen even as developing 6-o: problems of recognizing a leader, problems when enhancing policy and schedule for meetings and problems with identifying goals and responsibilities of all associates.

\section{The Shortcomings of Total Quality Management Implementation}

The major criticism emerged in opposition to TQM is that there is an extensive confusion relating to what TQM really means, notice (Boaden, 1997; Hellsten \& Klefsjo, 2000). Deming (1994) has avowed that: "...the trouble with TQM, the failure of TQM, you can call it, is that there is no such thing. It is a buzz word". I have never used the term, as it carries no meaning, perceive Romano (1994). Both TQM and Six Sigmaare concentrated on processes. Bergman \&"Klefsjo (2003) notice that: while Six Sigmafocalizes on performing enhancements, TQM stress the engagement and contribution of all workers.

Kekale \& Kekale (1995) suggest that perceiving TQM only just as a whole of tools and techniques (e.g. hard aspects) has confirmed to be one of the firstly failures of TQM implementation. The difficulty with TQM doesn't concern only the problem in defining the meaning of the term TQM, but more basically the confusion in defining quality Watson\& Korukonda, 1995). The unsuccessful execution of TQM cannot be neglected but in contrast it has been well documented, perceive (for example Brown,Hitchcock,\& Willard1994; Eskildson, 1994; Harari, 1997; Cao,Clarke, \& Lehaney, 2000; Nwabueze, 2001;Foley, 2004).In further specificity, Harari (1997) affirms that, subsequent to the examination of the entire independent research conducted by 
consulting companies, the finding is that just about one-fifth, or at best one-third, of the TQM programs in the US and Europe have attained important or even concrete enhance. Furthermore, the fall of the organizations number which have attempted the integration of TQM program have been documented. With extra specificity, a number of organizations have set a huge quantity of resources on executing TQM, however with no concrete development attained, perceive, among others (Harari, 1997). The TQM concept has been blamed for being vague.

In this work, we have stressed the decrease in adopting TQM and the increase of Six Sigmatrend. Thus, the fail in integrating TQM can be explained by many factors: TQM has been rather a diffused concept, with a lot of fuzzy descriptions but few more understandable definitions, and the management does not have an absolute image of what TQM in reality means (Hellsten \& Klefsjö, 2000). Pande,Neuman, \& Cavanagh, (2000) stated that TQM is less noticeable in several business. It was in the early 1990s, pointing to numerous major TQM mistakes as causes forthis decline. These problems contain a lack of integration, leadership apathy, a fuzzy concept, an ambiguous quality goal, failure to break down internal barriers, inadequate improvements in performance, and so on. However, many criticisms have attacked the Six Sigmamethodology. Frequently, it isn't considered as the newest in the field of quality management projects because large numbers of Six Sigmatechniques have been used and existed for a lot of years with TQM program.

The short attention to the behavioral and the change processes, reduce the chance of Six Sigmaprojects to attempt radical and sustainable process improvement. Six Sigmaprograms have not been designed to integrate all processes (work processes, behavioral processes, and change processes) in their process improvement efforts(Parast, 2011). The inability of Six Sigmaprograms to assure sustainable competitive advantage for the company because they are based on existing processes, products, and customers. This view point can be explained by the fact that it hasn't been constructed to attend radical enhancement in organizational processes and routines. (Parast, 2011).The integration of Six Sigmaprojects in a highly dynamic and evolving environment with high rate of innovation and change is extremely precarious due to the incapability of Six Sigmaprojects to achieve radical change. Thus, in defining and improving Six Sigmaprojects organizations should take caution when selecting projects that gratify the above conditions.

\section{Conclusion}

The Six Sigmaand the TQM approaches have been the subject of extensive researches and surveys for several years which provide a vital knowledge about their specific criteria. In fact, the Six Sigmamethodology focalized on reducing the process variation, and optimizing the process, while TQM is a method that aims to develop competitiveness, effectiveness and flexibility of an organization for the profit of each stakeholder (Srinivasu et al.,2010). The ambiguous aspect of TQM consists in the absence of a clear infrastructure to implement TQM in organization.

The TQM purpose as well as Six Sigmais the improvement of organizational performance. TQM emphasizes more on the satisfaction of the customer requirements in term of delivery, reliability, maintenance, and cost effectiveness (Al-Mashari \& Zairi, 2000a,b). However, a Six Sigma aim is to satisfy and to expect its needs. It focused specially to reduce the process variability in order to decrease the cost of reworks and the loss of time which lead to reduce the cost of non-quality translated into gain of saving, improvement of the product quality and service, reduction of customer's complaints and amelioration of the customer relationship and enhancement of the company trade. 
This paper focuses in the first part on the various definitions about the meaning of CSFs than specify besides its principal features for both Six Sigmaand TQM. The objective is to offer a clear vision about the similarities and dissimilarities between CSFs of Six Sigmaand TQM.

Antony \& Desai (2009) stress the existence of some characters of TQM that are imitated in Six Sigmaprogram and this is supported by "A customer-centric approach; process view of work; a continuous improvement mindset; improving all aspects and functions of the organization; data-based decision making ; and the use of statistical tools on a broad basis".

Kedar, Lakhe, Deshpande, Washimkar, \& Wakhare, (2008) consider that Six Sigmaprovides obvious change of structure and is greatly extra orientated on quick and concrete results compared to TQM and Lean. Näslund (2008) highlights that Six Sigmais an advance improvement of TQM.He discovers similarities in the problem solving process (Deming wheel and DMAIC cycle), the value of top management engagement, the crucial worker implication, and in statistical methods. The value added of Six Sigmaconsists in the well organized structure which focuses on strong difficulties solving techniques and tools based in the DMAIC support (Antony, 2009).

Furthermore, to sustain the results of previous studies considering Six Sigmaas an extension of TQM; we have outlined various studies of CSFs of Six Sigmaand TQM in different periods to prove their similar points and also to stress the distinctive aspects of Six Sigmawhich are: Six Sigmastructure procedure, Six Sigmastructure improvement procedure and Six Sigmafocus en metrics, and to emphasized the studies stressing the possibility of integrating Six Sigmavia TQM.

\section{References}

Abdullah, B. M. M., Uli, J., \& Tari, J.J. (2009). The relationship of performance with soft factors and quality improvement. Total Quality ManagementE Business Excellence.

20(7), 735-748.

Agus, A., \& Hassan, Z. (2011). Enhancing production performance and customer performance through Total Quality Management (TQM): Strategies for competitive advantage. Procedia Social \& Behavioral Sciences, 24, 1650-1662.

Aldowaisana, T., Nourelfathb, M., \& Hassan, J. (2015). Six Sigma Performance for Non-Normal Processes . European Journal of Operational Research, 247(3), 968-977.

Alidrisi, H. (2014). Prioritizing critical success factors for Six Sigma implementation using interpretive structural modeling. American Journal of Industrial \& Business Management, 4, 697-708.

Al-Mashari, M., \& Zairi, M. (2000a). “Revisiting BPR: A holistic review of practice and development. Business Process Management Journal, 6(1), p. 10.

Al-Mashari, M., \& Zairi, M. (2000b). Supply-Chain Re-Engineering using Enterprise Resource Planning (ERP) Systems: An analysis of a SAP R/3 implementation case. International Journal of Physical Distribution \& Logistics Management, 30(3/4), 296-313.

Anbari, F.T. (2002). Six Sigma Method and its Applications in Project Management. Proceedings of the Project Management Institute Annual Seminars \& Symposium [CD], Project Management Institute, Newtown Square, PA.

Anderersson, R., Eriksson, H., \& Torstensson, H. (2006). Similarities and differences between TQM, Six Sigma \& Lean. The TQM Magazine, 18(3), 282-96.

Antony, J. (2006). Six Sigma for service processes. Business Process Management Journal, 12(2), 234248.

Antony, J., \& Banuelas, R. (2001). A strategy for survival. Manufacturing Engineer, 80(3), 119-121. 
Antony, J., \& Banuelas, R. (2002). Key Ingredients for the effective implementation of Six Sigma program. Measuring Business Excellence, 6(4), 20-27.

Antony, J., Kumar, M., \& Madu, C.N. (2005). Six Sigma in small and medium size UK manufacturing enterprises'. International Journal of Quality \& Reliability Management, 22(8), pp. 860-74.

Badri, M.A., Davis, Donald., Davis, Donna. (1995). A study of measuring the critical factors of quality management. International Journal of Quality \& Reliability Management, 12(2), 3653.

Bendell, T., (2006). A Review and comparison of Six Sigma and the Lean organizations. The TQM Magazine, 18(3), 255-62.

Bergman, B., \& Klefsjo", B. (2003). Quality from customer needs to customer satisfaction

(2nd ed.). Studentlitteratur, Lund.

Boaden, R.J., (1997). What is Total Quality Management...and does it matter?.

Total Quality Management, 8(4), 153-71.

Brown, M.G., Hitchcock, D.E., \& Willard, M.L. (1994). Why TQM fails and what to do about it. Illinois: Irwin Professional Publisher.

Brun, A. (2011). Critical success factors of Six Sigma implementations in Italian companies. International Journal of Production Economics, 131(1), 158-164.

Cao, G., Clarke, S., \& Lehaney, B. (2000). A systematic view of organizational change and TQM. The TQM Magazine, 12(3), 186-93.

Carlos, J.F., Cândido., \& Sérgio, P. Santos. (2011). Is TQM more difficult to implement than other transformational strategies?. Total Quality Management \& Business Excellence. 22(11), 11391164.

Catherwood, P. (2002). What's different about Six Sigma. Manufacturing Engineer, 81(8), 186-189.

Chakravorty, S.S. (2009). Six Sigma Programs: An Implementation Model . International Journal of Production Economics. 119(1), 1-16.

Cheng, J.L. (2009). Six Sigma \& TQM in Taiwan: An empirical study of discriminate analysis.Total Quality Management \& Business Excellence, 20(3), 311-326.

Cheng, J.L. (2013). Linking Six Sigma to business strategy: An empirical study in Taiwan. Measuring Business Excellence, 17(1), 22-32.

Chinvigai, Ch., Dafaoui, E., \& EL Mhamedi, A. (2007). An approach for enhancing process and process interaction capability. 19th International Conference on Production Research, Valparaiso - Chile.

Choo, A.S., Linderman K.W., \& Schroeder R.G. (2007a). Method and psychological effects on learning behaviors and knowledge creation in quality improvement projects. Management Science, 53 (3), 437-450.

Choo, A.S., Linderman, K.W., \& Schroeder, R.G. (2007b). Method and context perspectives on learning and knowledge creation in quality management. Journal of Operations Management 25 (4), 918-931.

Dag, Näslund. (2008). Lean, Six Sigma and Lean Sigma: Fads or real process improvement methods?". Business Process Management Journal, Vol. 14(3), 269-287.

Dahlgaard, J.J., \& Dahlgaard-Park, S.M. (2006). Lean production, Six Sigma quality. $\quad$ TQM and company culture. The TQM Magazine, 18(3), 263-281.

Dahlgaard, J.J., Kristensen, K., \& Kanji, G.K. (1998). Fundamentals of Total Quality Management. Chapman \& Hall, Londo. 
Dalton, G., Perry, L., Younger, J., \& Smallwood, N. (1996). Strategic restructuring. Human Resources Management, 35(4), 433-52.

Das, A., Paul, H., \& Swierczek, F.W. (2008). Developing and validating Total Quality Management (TQM) constructs in the context of Thailand's manufacturing industry. Benchmarking: An International Journal, 15(1), 52-72.

Dasgupta, T. (2003). Using the Six-Sigma metrics to measure and improve the performance of a supply chain. Total Quality Management, 14, 355-366.

Dayton, N. (2003). The demise of Total Quality Management (TQM).

The TQM Magazine, 15(6), 391-6.

Deming, W.E. (1986). Out of a Crisis. Cambridge, MA: MIT Press.

Deming, W.E. (1994) . Report card on TQM. Management Review, 83(1), 22-5.

Demirbag, M., Tatoglu, E., Tekinkus, M., \& Zaim, S. (2006). An analysis of the relationship between total quality management implementation and organizational performance Turkish SMEs. Journal of Manufacturing Technology Management, 17(6), 829-47.

Desai, D.A., Antony, J., \& Patel, M.B. (2012).An Assessment of the critical success factors for Six Sigma Implementation in Indian industries. International Journal of Productivity \& Performance Management, 61(4), 426-444.

Douglas, P.C., \& Erwin, J. (2000). Six Sigma's focus on total customer satisfaction".

Journal for Quality \& Participation, 23(2), 45-49.

Eckes, G. (2001). Making Six Sigma last: Managing the balance between cultural and technical change. John Wiley \& Sons, New York, NY.

Ericsson E., Gingnell L., \& Lilliesköld, J. (2014): Implementing Design for Six Sigma in large Swedish product developing organisations - an interview study, Total Quality Management \& Business Excellence,26, (5/6), 648-660.

Eskildson, L. (1994). Improving the odds of TQM's success. Quality Progress, 27(4), 61-3.

Evans, J.R., \& Lindsay, W.M. (2005). The management and control of quality. Sixth ed, SouthWestern, Mason, Ohio.

Flynn, B.B. (1994). The relationship between quality management practices, infrastructure and fast product innovation. Benchmarking for Quality Management and Technology, 1(1), 48-64.

Foley, K. (2004). Five essays on quality management. SAI Global Ltd, Sydney.

Forrest, B. (2006). Green, Six-Sigma and the revival of TQM. Total Quality Management $\mathcal{E}$ Business Excellence,17(10), 1281-1286

Foster, Jr., S.T. (2007). Does Six Sigma improve performance. Quality Management Journal, 14(4), $7-20$.

Gaddene, D., \& Sharma, B. (2009). An investigation of the hard and soft quality management factors of Australian SMEs and their association with firm performance. International Journal of Quality \& Reliability Management, 26(9), 865-80.

Garvin, D., (1995). Leveraging processes for strategic advantage. Harvard Business Review, September/October, 77-90

Glibert, B. (2002). Sick Sigma?. Retrieved from www.contextmag.com/archives/200208/ Feature2SickSigmma.asp?

Goh, T.N. (2010). Six Triumphs and six tragedies of Six Sigma. Quality Engineering. 22(4), 299305.

Green, F. (2006). Six Sigma and the revival of TQM. Total Quality Management and Business Excellence, 17(10), 1281-6. 
Grima, P., Marco-Almagro, L., Santiago, S., \& Tort-Martorell, X. (2014). Six Sigma: Hints from practice to overcome difficulties. Total Quality Management, 25(3), 198-208.

Hackman, J.R., \& Wageman, R. (1995). Total Quality Management: Empirical, conceptual and practical implications. Administrative Science Quarterly, 40(2), 309-342.

Haleema , A., Sushilb., Qadric M.A., \& Kumarc S.(2012). Analysis of critical success factors of world-class manufacturing practices: an application of interpretative structural modelling and interpretative ranking process. Production Planning \& Control, 23(10-11).

Hammer, M., \& Champy, J. (1993). Reengineering the corporation: A manifesto for business revolution. Harper Business, New York, NY.

Harari, O. (1997). Ten Reasons why TQM doesn't work. Management Review, 86(1), 38-44.

Harry, M. (1998). Six Sigma: a breakthrough strategy for profitability. Quality Progress, 31(5), 60 64.

Harry, M.J., \& Schroeder, R. (2000). "Six Sigma: The breakthrough management strategy revolutionizing the world's top corporations". Currency, New York, NY

Harry, M.J., \& Schroeder, R. (2000). Six Sigma. New York: Bantam Audio.

Hellsten, U., \& Klefsjo," B. (2000). TQM as a management system consisting of values, techniques and tools. TQM Magazine, 12(4), 238-44

Hietschold, N., Reinhardt R., \& Gurtner S. (2014). Measuring critical success factors of TQM implementation successfully - a systematic literature review. International Journal of Production Research. 52(21), 6254-6272.

Hilton, R., Balla, M., \& Sohal, A.S. (2008). Factors critical to the success of a Six Sigma quality program in an Australian hospital. Total Quality Management \& Business Excellence, 19(9), 887-902.

Hiregoudar, N. L., \& Soragaon, B. (2011). On some aspects of developing an effective model for the implementation of Six Sigma concept in small and medium sized manufacturing enterprises in India.International Journal of Management Science and Engineering Management, 6 (1), 42-48.

Hoerl, R.W. (1998). “Six Sigma and the future of quality profession”. Quality Progress,

31(6), 35-42.

Hu, M., Barth, B., \& Sears, R. (2005). Leveraging Six Sigma disciplines to drive improvement. International Journal of Six Sigma \& Competitive Advantage, 1(2), 121-33.

Ismyrlis, V., \& Moschidis, O. (2013). Six Sigma's critical success factors and toolbox. International Journal of Lean Six Sigma, 4(2), 108 - 117.

Johnson, K. (2005). Six Sigma delivers on-time service. Quality Progress, 38(12), 57-59.

Jones, E.C., Perast, M.M., \& Adams, S.G. (2011). Developing an instrument for measuring Six Sigma implementation.Int. J. Services \& Operations Management, 9(4), 429-452.

Jun, M., Cai, S., \& Peterson, R. (2010).Total Quality Management \& Business Excellence. 15(1), pp. 5972

Juran, J. (1989). Juran on leadership for quality: An executive handbook. The Free Press, New York, NY.

Kalra, N., \& Pant, A. (2013). Critical success factors of total quality management in the Indian automotive industry (NCR). International Journal of Economy, Management $\mathcal{E}$ Social Sciences, 2(8), 620-625.

Kanji, G.K., \& Yui, H. (1997). Total quality culture. Total Quality Management, 8(6),

$417-$ 428. 
Karuppusami, G., \& Gandhinathan, R. (2006). Pareto analysis of critical success factors of total quality management a literature review and analysis". The TQM Magazine, 18(4), 372385.

Kedar, A.P., Lakhe, R. R., Deshpande, V. S., Washimkar, P. V., \& Wakhare, M.V. (2008). comparative review of TQM, TPM and related organizational performance improvement programs. ICETET '08, First International Conference on Emerging Trends in Engineering \& Technology.

Keen, G., \& Knapp, M. (1996). Every manager's guide to business processes: A glossary of key terms $\mathcal{E}$ concepts for today's business leader. Harvard Business School Press, Boston, MA.

Kekale, T., \& Kekale, J. (1995). A Mismatch of Cultures: A Pitfall of Implementing a Total Quality Approach. International Journal of Quality \& Reliability Management, 12(9), 210220.

Khaidir, N.A., Habidin, N.F., Jamaludin, N.H., Shazali, N.A., \& Ali, A. (2014). Investigation of Six Sigma practices and process innovation for Malaysian healthcare industry. International Journal of Innovation \& Applied Studies, 5(2), 131-138.

Khanna, H.K., Sharma, D.D., \& Laroiya, S.C. (2011). Identifying and ranking critical success factors for implementation of Total Quality Management in the Indian manufacturing industry using TOPSIS. Asian Journal on Quality, 12(1), 124-138.

Klefsjo, B., Bergquist, B., \& Edgeman, R. (2006). Six Sigma and Total Quality Management: different day, same soup?. International Journal of Six Sigma \& Competitive Advantage, 2(2), $162-78$.

Klefsjo", B., Wiklund, H., \& Edgeman, R.L. (2001). Six Sigma seen as a methodology for Total Quality Management. Measuring Business Excellence, 5(1), 31-5.

Knowles, G. (2011). Six Sigma. Ventus Publishing.

Koh, T.Y., \& Low, S.P. (2010). Empiricist framework for TQM implementation in construction companies. J. Mgmt. in Engrg, 26(3), 133-43

Kotler, P.H. (1994). Marketing Management: Analysis, Planning, Implementation and Control (8th ed.). Prentice Hall, New Jersey.

Kumar, V., Choisne, F., Grosbois, D., \& Kumar, U. (2009). Impact of TQM on company's performance. International Journal of Quality \& Reliability Management. 26(1), 2337.

Kutlu,A.C., \& Kadaifci, C. (2014). Analyzing critical success factors of Total Quality management by using fuzzy cognitive mapping. Journal of Enterprise Information Management, 27(5), 561-575.

Kwak, H.Y., \& Anbari, F.T. (2006). Benefits, obstacles, and future of Six Sigma approach. Technovation, 26(5-6), 708-715.

Lakhal, L., Pasin, F., \& Limam, M. (2006). Quality management practices and their impact on performance. International Journal of Quality \& Reliability Management, 23(6), 625-646.

Leong, T.W., \& The, P.L. (2012). Critical success factors of Six Sigma in original equipment manufacturer company in Malaysia. International Journal of Synergy \& Research, 1(1), 7-21.

Lewis, W.G., \& Lalla, T.R.M. (2006). Exploring soft versus hard factors for Total Quality Management Implementation in SMEs. International Journal of Productivity \& Performance Management. 55(7), 539- 554.

Linderman, K., Shroeder, R., Zaheer, S., \& Choo, A.S. (2003). Six Sigma: A goal theoretic perspective. Journal of Operations Management, 21 2), 193-203. 
Lucas, J.M. (2002). The essential Six Sigma. Quality Progress, 35(11), 27-32.

Magnusson, K., Kroslid, D., \& Bergman B. (2003). Six Sigma. The pragmatic approach. ed.). Lund, Studentlitteratur.

Mahdi, O.R., \& Almsafir, M.K. (2012). Diagnosing of sustainable competitive advantage using Six Sigma methodology. International Journal of Business \& Management, 7(7).

Mann, Nancy R., (1992). The keys to excellence: The Deming philosophy. Kuala Lumpur: Abdul Majeed \& Co.

March, J.G. (1991). Exploration and exploitation in organizational learning. Science, 2(1), 71-87.

Mast, J. (2004). A methodological comparison of three strategies for quality improvement. International Journal of Quality \& Reliability Management, 21(2), 198-213.

Montgomery, D.C., \& Woodall, W.H. (2008). An overview of Six Sigma.

International Statistical Review, 76 (3), 329-346.

Moosa, K., \& Sajid, A. (2010). Critical analysis of Six Sigma implementation. Total Quality Management and Business Excellence, 21(7), 745-759.

Mosadeghrad, A.M. (2014). Essentials of Total Quality Management:

A meta-analysis. International Journal of Health Care Quality Assurance, 27(6), 544 - 558.

Mosadeghrad, A.M. (2014). Why TQM programmes fail? A pathology approach.

The TQM Journal, 26(2), 160 - 187.

Na"slund, D. (1996). On performance measurement systems: design and development. University, Lund.

Naslund, D. (2008). Lean, Six Sigma and Lean sigma: Fads or real process improvement methods?. Business Process Management Journal, 14(3), 269-287.

Natarajan, M., Senthil, V., Devadasan, S.R., \& Vijay Mohan, N. (2011).

Quarnewss: A Model for applying Six Sigma framework to achieve continuous quality and reliability improvement in new product development. Int. J. Productivity $\mathcal{E}$ Quality Management, 7(1).

Nwabueze, U. (2001). An industry betrayed: The case of Total Quality Management in manufacturing. The TQM Magazine, 13(6), 400-8.

Pande, P.S. (2002). What is Six Sigma?. New York: McGraw -Hill

Pande, P.S., Neuman, R.R., \& Cavanagh, R.R. (2000). The Six Sigma way. McGraw-Hill, New York, NY.

Parast, M.M.(2011). The effect of Six Sigma projects on innovation and firm performance. International Journal of Project Management, 29, 45-55.

Pepper, M.P.J., \& Spedding, T.A. (2010). The evolution of Six Sigma. International Journal of Quality and Reliability Management, 27(2), 138-55.

Powel, T. (1995). Total Quality Management as competitive advantage: A review and empirical study. Strategic Management Journal, 16(1), 15-37.

Prajogo, D.I., \& Sohal, A.S. (2001). The relationship between TQM practices and innovation performance: a literature review and research framework. Technovation, 21(9), 539-558.

Raghunath, \& Jayathirtha. (2013). Critical success factors for Six Sigma implementation by SMEs. International Journal of Scientific \& Engineering Research, 4(2).

Rahman, \& Bullock, P. (2005). Soft Total Quality Management, hard Total Quality Management, \& organizational performance relationship. The International Journal of Management Science, 33, 73-83. 
Rahman, S. (2001) .A comparative study of TQM practice and organizational performance of SMEs with and without ISO 9000 certification. International Journal of Quality \& Reliability Journal, 18(1), 35-49.

Rahman, S. (2007). The future of TQM is past. Can TQM be resurrected?.

Total Quality Management \& Business Excellence. 15(4), 411-422.

Raisinghani, M.S., Ette, H., Pierce, R., Cannon G., \& Daripaly P. (2005). Six Sigma: concepts, tools, and applications. Industrial Management and Data Systems, 105(3/4), 491-505.

Rezazadeh, A., Najafi, S., Loghman, H.S., Sina, M.N. (2012). Evaluating and prioritizing critical success factors of TQM implementation based on fuzzy AHP.

International Journal of Productivity \& Quality Management, 9(1), 1-24.

Roberts, C.M. (2004). Six Sigma signals. Credit Union Magazine, 70 (1), 40-43.

Roffe, I., (1999). Innovation and creativity in organizations: A review of the implications for training and development. Journal of European Industrial Training, 23(4/5), 224-237.

Romano, C. (1994). Report card on TQM. Management Review, 83(1), 22-5.

Rucker, R. (2000). Citibank increases customer loyalty with defect-Free Processes. Journal for Quality \& Participation, 23(4), 32-36.

Sabet, E.,Adams, E., \&Yazdani, B.(2014). Quality management in heavy duty manufacturing industry: TQM vs. Six Sigma. Total Quality Management \& Business Excellence, 1-11.

Salaheldin, I.S., (2009). Critical success factors for TQM implementation and their impact on performance of SMEs. International Journal of Productivity \& Performance Management, 58 (3), 215-237.

Sambhe, R.U., \& Dalu, R.S. (2011). An empirical investigation of Six Sigma implementation in medium scale Indian automotive enterprises. Int. J. Productivity \& Quality Management, $8(4), 480-501$.

Schroeder, R.G., Linderman, K., Liedtke, C., \& Choo, A.S. (2008). Six Sigma: Definition and underlying theory. Journal of Operations Management, 26(4), 536-554.

Shafer S.M., \& Moeller S.B., (2012). The Effects of Six Sigma on corporate performance: An empirical investigation. Journal of Operations Management, 30, 521-532.

Shahin, A. (2011). An investigation on the influence of Total Quality Management on financial performance the case of Boutan industrial corporation. International Journal of Business $\mathcal{E}$ Social Science. 2(15).

Shetty, Y.K. (1987). Product quality and competitive strategy. Business Horizon,

$46-$ 52.

Shiba, S., Graham, A., \& Walden, D. (1993). A new American TQM: Four practical revolutions in management. Portland, Oregon, Centre for Quality Management, Productivity Press.

Sila, I., \& Ebrahimpour, M. (2002). An investigation of the Total Quality Management.19, (7), 903971.

Sinha, K.K., Van de Ven, A.H. (2005). Designing work within and between organizations. Organization Science, 16(4), 389-408.

Somsuk, N., \& Simcharoen, C. (2011). A fuzzy AHP approach to prioritization of critical success factors for Six Sigma implementation: Evidence from the electronics industry in Thailand. International Journal of Modeling \& Optimization, 1(5), 432-437.

Sony, M., \& Naik, S. (2012). Six Sigma, organizational learning and innovation: an integration and empirical examination. International Journal of Quality \& Reliability Management, 29(8), 915 -936. 
Spector, R. (2006). How constraints management enhances Lean and Six Sigma. Chain Management Review, 10(1), 42-7.

Srinivasu, R., Reddy, G.S., Sreenivasarao, V., \& Rikkula, S.R. (2010). The contributions of TQM and Six Sigma in the organizations to achieve the success in term of quality. International Journal of Reviews in Computing, 8-18.

Swami , P.S., \& Prasad, V.M. (2010). Critical success factors for Six Sigma implementation. Journal of Contemporary Research in Management.5(3), 83-91.

Swink, M., \& Jacobs, B.W. (2012). Six sigma adoption: operating performance impacts and contextual drivers of success. Journal of Operations Management. 30(6), 437-453.

Tar'', J. (2005). Components of successful Total Quality Management. The TQM Magazine, 17(2), p. 182.

Thawani, S. (2004). Six Sigmastrategy for organizational excellence. Total Quality Management \& Business Excellence, 15(5), 655-664.

Tillery, K.R., \& Rutledge, A.L. (1991). Quality strategy and quality management connections. International Journal of Quality \& Reliability Management (IJQ), 8(1), 71-77.

Tlapa, D.A., Leal, J.S., Amaya, G., Limón, J., \& Báez, Y.A. (2010). Six Sigma'S success factors: A meta-analytic review. International Conference on Industrial Engineering Theory, Applications \& Practice Mexico City, Mexico October 17-20.

Tlapa, D.A., Sánchez, J., Aguilar, J., Limón, J., \& De la Vega, E. (2011). An exploration of Six Sigma'S tools and techniques. International Conference on Industrial Engineering. Theory, Applications \& Practice. Stuttgart, Germany September 20-23.

Voehl, F. (2004). Six Sigma community improvement project. Quality Congress, ASQ's Annual Quality Congress Proceedings, Vol. 58, pp. 351-64.

Watson, J.G., \& Korukonda, A.R. (1995). The TQM jungle: A dialectical analysis. International Journal of Quality \& Reliability Management, 12(9), 100-109.

Winter, S. (1994). Organization for continuous improvement: evolutionary theory meets the quality revolution. Evolutionary Dynamics of Organizations. In Baum J.A.C., \& Singh, J.V. (Eds), Evolutionary Dynamics of Organizations (pp.90-108). Oxford University Press, Oxford.

Yang, C.C. (2003a). The establishment of a TQM system for the health care industry.

The TQM Magazine, 15(2), 93-98.

Yang, C.C. (2012). Chapter 9. In Licensee InTech (Eds), Total Quality Management and Six Sigma : The Integration of TQM and Six-Sigma (pp.219-246).

Yang, C.C., (2004). An integrated model of TQM and Six-Sigma. International Journal of Six Sigma $\mathcal{E}$ Competitive Advantage, 1(1), 97-111.

York, K.M., \& Miree, C.E. (2004). Causation or Covariation: An empirical re-examination of the link between TQM and financial performance. Journal of Operations Management, 22, 291311.

Yusof, S.M., \& Aspinwall, E. (2000). Critical success factors for total quality management implementation in small and medium enterprises. Total Quality Management, 10(4-5), 803809.

Zairi, M. (1998). Benchmarking for Best Practice: Continuous Learning through Sustainable Innovation. Butterworth-Heinemann. Oxford.

$\mathrm{Zu}$, X., Fredendall, L.D., \& Douglas, T.J. (2008). The evolving theory of quality management: the role of Six Sigma. Journal of Operations Management, 26(5), 630-650. 
Journal of Management and Economic Studies, vol.2, issue.4, pp.198-226

Zu, X., Robbins, T.L., \& Fredendall, L.D. (2010). Mapping the Critical Links between Organizational Culture \& TQM/Six Sigma Practices. International Journal of Production Economics, 123(1), 86-106. 